Pacific Journal of Mathematics

A NOTE ON AN INEQUALITY FOR REARRANGEMENTS 


\section{A NOTE ON AN INEQUALITY FOR REARRANGEMENTS}

\section{CHRISTER BORELL}

If $a=\left(a_{1}, \cdots, a_{n}\right)$ is a $n$-tuple of positive real numbers let $a^{+}=\left(a_{1}^{+}, \cdots, a_{n}^{+}\right)$denote the rearrangement of $a$ in increasing order and $a^{-}=\left(a_{1}^{-}, \cdots, a_{n}^{-}\right)$the rearrangement of $a$ in decreasing order. In this note a characterization is given for those functions $f: R_{+} \rightarrow R$ such that

$$
\sum_{1}^{n} f\left(\frac{a_{k}^{+}}{b_{k}^{+}}\right) \leqq \sum_{1}^{n} f\left(\frac{a_{k}}{b_{k}}\right) \leqq \sum_{1}^{n} f\left(\frac{a_{k}^{+}}{b_{k}^{-}}\right)
$$

holds for all $a, b \in R_{+}^{n}$. Here $n$ is a fixed integer $>1$.

In [3] Minc proved that

$$
\prod_{1}^{n}\left(a_{k}^{+}+b_{k}^{+}\right) \leqq \prod_{1}^{n}\left(a_{k}+b_{k}\right) \leqq \prod_{1}^{n}\left(a_{k}^{+}+b_{k}^{-}\right) .
$$

This inequality was generalized by London [1, Theorem 1], who (in an equivalent form) proved that (1) holds if the function $f\left(e^{x}-1\right), x \geqq 0$, is convex and $f(x) \geqq f(0), x>0$.

London [1, Theorem 2] also proved (1) if $f$ is convex and $f(x) \geqq$ $f(0), x>0$, which in fact is contained in the previous case.

The proofs in [1] are based on an interesting representation theorem of Mirsky.

The purpose of this note is to characterize those functions $f$, for which (1) holds.

The left inequality in (1) is in fact a special case of a theorem of Lorentz [2, Theorem 1]. This theorem especially gives, that if $\Phi=\Phi(u, v)$ belongs to $C^{(2)}\left(\boldsymbol{R}_{+} \times \boldsymbol{R}_{+}\right)$then

$$
\sum_{1}^{n} \Phi\left(a_{k}^{+}, b_{k}^{+}\right) \leqq \sum_{1}^{n} \Phi\left(a_{k}, b_{k}\right) \quad \text { all } \quad a, b \in \boldsymbol{R}_{+}^{n} \quad(n>1)
$$

if and only if

$$
\frac{\partial^{2} \Phi}{\partial u \partial v} \leqq 0
$$

From this it is fairly easy to deduce that (2) and (3) are both equivalent to

$$
\sum_{1}^{n} \Phi\left(a_{k}, b_{k}\right) \leqq \sum_{1}^{n} \Phi\left(a_{k}^{+}, b_{k}^{-}\right) \quad \text { all } \quad a, b \in \boldsymbol{R}_{+}^{n} \quad(n>1) .
$$

We shall give an independent proof of these equivalences, which differs from that given in [2]. 
Let $a, b \in \boldsymbol{R}_{+}^{n}$ and choose $\varepsilon \in \boldsymbol{R}_{+}$such that $\varepsilon<\min \left(\min a_{k}\right.$, $\left.\min b_{k}\right)$. If $A$ is a finite set, let $|A|$ denote the number of distinct elements in $A$.

By adding the identities

$$
\begin{aligned}
\Phi\left(a_{k}, b_{k}\right) & =\Phi(\varepsilon, \varepsilon)-\Phi\left(a_{k}, \varepsilon\right)-\Phi\left(\varepsilon, b_{k}\right)+\int_{\varepsilon}^{a_{k}} \int_{\varepsilon}^{b_{k}} \frac{\partial^{2} \Phi}{\partial u \partial v} d u d v, \\
k & =1, \cdots, n,
\end{aligned}
$$

we have

$$
\begin{gathered}
\sum_{1}^{n} \Phi\left(a_{k}, b_{k}\right)=n \Phi(\varepsilon, \varepsilon)-\sum_{1}^{n} \Phi\left(a_{k}, \varepsilon\right)-\sum_{1}^{n} \Phi\left(\varepsilon, b_{k}\right) \\
+\int_{\varepsilon}^{\infty} \int_{\delta}^{\infty}\left|\left\{k \mid a_{k} \geqq u, b_{k} \geqq v\right\}\right| \frac{\partial^{2} \Phi}{\partial u \partial v} d u d v .
\end{gathered}
$$

Set

$$
N(a, b ; u, v)=\left|\left\{k \mid a_{k} \geqq u, b_{k} \geqq v\right\}\right| \text {. }
$$

Then

$$
N\left(a^{+}, b^{-} ; u, v\right) \leqq N(a, b ; u, v) \leqq N\left(a^{+}, b^{+} ; u, v\right)
$$

and so (2) and (4) follow from (3) and (5).

To prove, (4) implies (3), set

$$
D(u, v)=N(a, b ; u, v)-N\left(a^{+}, b^{-} ; u, v\right) .
$$

In view of (5), (4) is then equivalent to

$$
\int_{0}^{\infty} \int_{0}^{\infty} D(u, v) \frac{\partial^{2} \Phi}{\partial u \partial v} d u d v \leqq 0
$$

If (4) holds for some $n>1$, then it also holds for $n=2$. To see this we only need to apply (4) to the $n$-tuples $a=\left(a_{1}, a_{2}, \varepsilon, \cdots, \varepsilon\right)$ and $b=\left(b_{1}, b_{2}, \delta, \cdots, \delta\right)$, where $\varepsilon>\max \left(a_{1}, a_{2}\right)$ and $0<\delta<\min \left(b_{1}, b_{2}\right)$.

Choose $0<u_{1}<u_{2}, 0<v_{1}<v_{2}$ and set $a_{1}=u_{1}, a_{2}=u_{2}, b_{1}=v_{1}$ and $b_{2}=v_{2}$. Then $D(u, v)=1$ if $u_{1}<u \leqq u_{2}, v_{1}<v \leqq v_{2}$ and $=0$ elsewhere. Therefore (3) follows from (6).

Analogously we can prove that (2) implies (3).

In [2] there are also necessary and sufficient conditions on $\Phi$ in order for (2) ((4)) to hold, when $\Phi$ is only continuous. It is easy to see that $(2) \Leftrightarrow(3) \Leftrightarrow(4)$ in this case too, if (3) is interpreted in the distribution sense, that is the left-hand side is a negative measure. A formal proof goes via regularization of $\Phi$.

We now return to the inequality (1). This corresponds to 


$$
\Phi(u, v)=f\left(\frac{u}{v}\right)
$$

which gives

$$
\frac{\partial^{2} \Phi}{\partial u \partial v}=-\frac{1}{v^{2}}\left\{f^{\prime \prime}\left(\frac{u}{v}\right) \cdot \frac{u}{v}+f^{\prime}\left(\frac{u}{v}\right)\right\} \leqq 0,
$$

that is

$$
f^{\prime \prime}(x) \cdot x+f^{\prime}(x) \geqq 0, \quad x>0 \text {. }
$$

This means that (1) holds if and only if the function $f\left(e^{x}\right)$, $-\infty<x<+\infty$, is convex.

\section{REFERENCES}

1. D. London, Rearrangement inequalities involving convex functions, Pacific J. Math., 34 (1970), 749-753.

2. G. G. Lorentz, An inequality for rearrangements, Amer. Math. Monthly, 60 (1953), 176-179.

3. H. Minc, Rearrangement inequalities (to appear).

Received March 1, 1972.

UNIVERSITY OF UPPSALA 



\section{PACIFIC JOURNAL OF MATHEMATICS}

\section{EDITORS}

D. Gilbarg and J. Milgram

Stanford University

Stanford, California 94305

R. A. Beaumont

University of Washington

Seattle, Washington 98105
J. DUGUNDJI* Department of Mathematics

University of Southern California Los Angeles, California 90007

RICHARD ARENS

University of California

Los Angeles, California 90024

\section{ASSOCIATE EDITORS}

E. F. BeCKenbach

B. H. NeUMaNN

F. WOLF

K. Yoshida

\section{SUPPORTING INSTITUTIONS}

UNIVERSITY OF BRITISH COLUMBIA

UNIVERSITY OF SOUTHERN CALIFORNIA

CALIFORNIA INSTITUTE OF TECHNOLOGY

UNIVERSITY OF CALIFORNIA

MONTANA STATE UNIVERSITY

STANFORD UNIVERSITY

UNIVERSITY OF TOKYO

UNIVERSITY OF NEVADA

UNIVERSITY OF UTAH

NEW MEXICO STATE UNIVERSITY

WASHINGTON STATE UNIVERSITY

OREGON STATE UNIVERSITY

UNIVERSITY OF OREGON

OSAKA UNIVERSITY

UNIVERSITY OF WASHINGTON

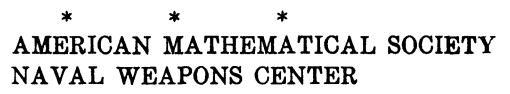

* C. DePrima will replace J. Dugundji until August 1974. 


\section{Pacific Journal of Mathematics}

\section{Vol. 47, No. $1 \quad$ January, 1973}

K. Adachi, Masuo Suzuki and M. Yoshida, Continuation of holomorphic

mappings, with values in a complex Lie group ....................

Michael Aschbacher, A characterization of the unitary and symplectic groups

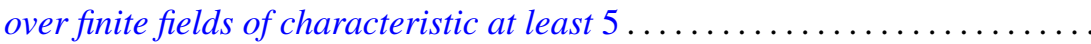

Larry Eugene Bobisud and James Calvert, Energy bounds and virial theorems for abstract wave equations....................................

Christer Borell, A note on an inequality for rearrangements ................

Peter Southcott Bullen and S. N. Mukhopadhyay, Peano derivatives and general

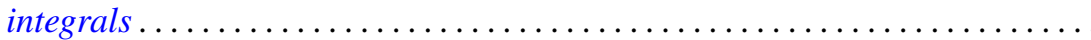

Wendell Dan Curtis, Yu-Lee Lee and Forrest Miller, A class of infinite dimensional subgroups of $\operatorname{Diff}^{r}(X)$ which are Banach Lie groups .........

Paul C. Eklof, The structure of ultraproducts of abelian groups ...............

William Alan Feldman, Axioms of countability and the algebra $C(X) \ldots \ldots \ldots$

Jack Tilden Goodykoontz, Jr., Aposyndetic properties of hyperspaces...........

George Grätzer and J. Płonka, On the number of polynomials of an idempotent algebra. II ...........................................

Alan Trinler Huckleberry, The weak envelope of holomorphy for algebras of

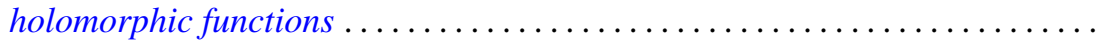

John Joseph Hutchinson and Julius Martin Zelmanowitz, Subdirect sum decompositions of endomorphism rings . . . . . . . . . . . . . . . .

Gary Douglas Jones, An asymptotic property of solutions of

$y^{\prime \prime \prime}+p y^{\prime}+q y=0$.

Howard E. Lacey, On the classification of Lindenstrauss spaces .

Charles Dwight Lahr, Approximate identities for convolution measure algebras.

George William Luna, Subdifferentials of convex functions on Banach

spaces.

Nelson Groh Markley, Locally circular minimal sets. .

Robert Wilmer Miller, Endomorphism rings of finitely generated projective modules

Donald Steven Passman, On the semisimplicity of group rings of linear

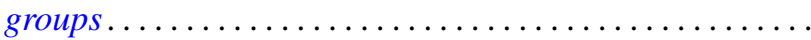

Bennie Jake Pearson, Dendritic compactifications of certain dendritic spaces.

Ryōtarō Satō, Abel-ergodic theorems for subsequences ...... .

Henry S. Sharp, Jr., Locally complete graphs. . .

Harris Samuel Shultz, A very weak topology for the Mikusinski field of

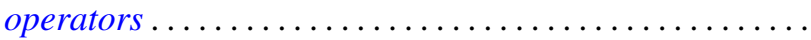

Elena Stroescu, Isometric dilations of contractions on Banach spaces ...

Charles W. Trigg, Versum sequences in the binary system ... . .

William L. Voxman, On the countable union of cellular decompositions of n-manifolds 